religious feelings are also most closely connected with ethical emotion and rest upon it." This part closes with a chapter on quantity and duration of emotion, in which a yariety of topics such as emotional expression, the association and conflict of emotion, and the like are handled.

Part Fourth (pp. 308-372) consists of chapters on the Motor Consciousness, Stimuli to Involuntary Movement, Stimuli to Voluntary Movement, Voluntary Movement, Volition. Exception will be taken to much that is said or implied bere, according as one agrees or disagrees with the author's general philosophical position. The facts, however, are carefully and impartially presented; and the discussion as regards both matter and form is superior to what is usually found in elementary works. This third part does much to give completeness to the work.

We have reviewed this book at such length for the reason that in spite of all the defects to which we have alluded, and others which we have passed over, we regard it as, on the whole, the best elementary text-book on psychology for use in academies, high-schools, and our smaller colleges now before the public. It is written from the scientific standpoint and in a thoroughly scientific spirit by one versed in the literature and acquainted with the latest advances of the science. The only other book which can compete with it is Professor James' Briefer Psychology. It lacks the brilliant qualities of James' book, while, on the other hand, it is more systematic and complete and hence better adapted for a text-book. The two books admirably supplement each other. If the one could be used as a required text-book and the other as supplementary reading, we believe that elementary instruction in psychology would be vastly improved. The mechanical makeup of the book is excellent; but the publishers should see to it that an index is added.

Grorge Martin Duncan.

YARE UNTVRRSITY.

\title{
CHILD-PSYCHOLOGY.
}

L'Evolution intellectuelle et morale de Ienfant. G. Compayre. Paris, Hachette, 1893. Pp. xxiv + 37x.

The Psychology of Childhood. Fred. Tracy. Boston, Heath \& Co., 1893. Pp. 94.

In the present condition of the study of the psychology of childhood, books of two classes are necessary aside from the detailed records of exact observations and experiments. We need first of all summaries which shall offer us from time to time exact and minutely-detailed topical statements of all observations already made by everybody and 
everywhere. Such statements are necessary, if reliable and exhaustive, to all who are themselves making observations or using them for purposes of interpretation. The second class of works which are needed, and which alone truly represent the object of the study, are works of interpretation and theory whereby the net results of the observations of all workers are made available for general psychological theory, especially on its genetic side.

The work of Compayre is not adapted to either of these purposes, nor does the author himself make new observations of importance on children. His book-magnificently printed on very heavy paper with wide margins-follows the French traditions on this topic. He covers the whole field in a pleasant, too-talkative style, stating old hypotheses clearly and well, without too much criticism, and failing to bring-as Perez fails to bring - the observations cited into range of the more important genetic questions ot later discussion by psychologists. Apart from interesting aperfus on minor points-such as the dependence of the child's memory on present objects ( 127 and ${ }^{2} 39$ ), the recognition of 'automatic' imitation ( $18 \mathrm{r}$ ), etc., I find no important gain either to theory or fact. The book, however, will do good service as an 'Introduction ' to the subject for raders who want to know the general state of the questions at issue and the nature of earlier observations and literature. It is probably the best book of this character; and possibly this is what the author had mainly in mind.

Tracy's work falls distinctiy under the first of the two useful categories I have mentioned-a remark which I have a right to make, since it was undertaken at my suggestion and much of it written in consultation with myself with the purpose explained above in view.* As far as the carrying out of this purpose-to produce a condensed objective statement, by topics, of all work done to date everywhere-as far as this is concerned, the work is to be heartily commended. Tracy covers the literature much better than Compayre (who, for example, makes no reference, I think, to American work). He is also less subjective, although in this respect some of his sections might be further improved. The chapter on 'Language,' moreover, makes contribution to the theory of infant speech-a point which was spoken of by Prof. Dewey in the last issue of this Review (r. p. 63 f.). I have, therefore, no hesitation in endorsing the words used by President Hall in his preface: "This work was greatly needed, and has been done with a thoroughness which all interested in the subject must gratefully recognize." The real value of the book, however, for its purpose, is almost entirely negatived by its external blemishes and deficiencies. It has neither table of contents

- See the author's note, B. p. go. 
nor index : a most remarkable double oversight in a book whose raison d'stre is ready reference. Suppose a reader desirous of knowing all the observations hitherto made on the infant's 'walking reflex ': he has not only no way to find this topic, but, further, no way to find the chapter in which it occurs-except as he may turn pages until he find the chapter on 'Volition', and then look through that until he find a section which would 'seem likely' (such a section as 'reflex movement') -and explore that until, not finding what he wants (as he would not find this particular topic; it is probably an omission, though it may be where I have not looked), he would have spent and lost his time. It would seem necessary, if the book is to do what its excellences really fit it to do, that a detailed index should be prepared and sold with the work It could then be bound in by the purchaser. Further blemishes, also, increase one's sense of the extreme carelessness of some responsible party. The print of the text is ruinous to the eyes in any light but daylight, and the foot-notes would arouse the laboris amor of histologists. Further, there are three typographical errors on the first three-quarter page of Chapter I, and the proportion seems to be pretty well kept up throughout. Nothing but a new edition would correct these blemishes : and it is to be hoped, in view both of the late results which should be frequently incorporated, and of the merit of the author's labor, that a new edition may soon appear. In that case it is to be hoped that Dr. Tracy will not again allow his work to be so mangled.

J. M. B.

\section{THE NERVOUS SYSTEM.}

Die trophischen Eigenschaften der Nerven. J. Gaule. Berliner Klin. Wochensch. Nos. 44 and $45 . \quad 1893$.

Die trophischen Eigenschaften der Nerven. J. GavLE. Auszug aus dem in Nürnberg auf der Naturforscherversammlung gehaltenen Vortrage. Centralb. f. Nervenh. und Psych., Nov. 1893.

The background of organic processes of which our special sensations form the visible surface is of recognized psychological importance. From the physiological side this background may be considered as the total result of those activities of the nervous system which are called trophic, and hence an interest attaches for us to any advances in this field.

The titles given above refer to a running account of the general conclusion at which Gaule has arrived after experimenting for several years. He establishes his theoretical standpoint by dividing the forces acting upon the living organism into two groups : the group which we 